\title{
Hepatitis G Virus Infection in Patients with Hepatitis C
}

Heba S. Selim*, Mohamed A.El Barrawy*, Osama N. Mohamed*, Marwa S. Gamal El Din*.

\begin{abstract}
Hepatitis G virus (HGV) infection is a worldwide health problem causing acute and chronic non A- E hepatitis. Because HGV and hepatitis $C$ virus (HCV) share same modes of transmission, co-infection with the two viruses is not uncommon especially among people at high risk of parenteral infection. The aim of this study was to determine the prevalence of HGV among HCV virus cases, and to determine the degree of concurrent association between HGV and other prevalent infections in Egypt as Schistosoma, and hepatitis B virus (HBV) infections. This study included 100 blood donors attending Alexandria University Blood Bank in EL Shatby, proved to be positive for HCV antibodies by enzyme linked immunosorbant assay (ELISA) technique. Blood samples were collected and tested for the detection of HBV surface antigen (HBsAg) and Schistosoma antibodies by ELISA technique and HGV RNA by nested polymerase chain reaction (PCR) technique. Out of 100 anti-HCV positive blood donors, 39(39\%) had HGV RNA in their serum, of them 10 (25.6\%) were positive for HBsAg, on the other hand 34(87.2\%) were positive for Schistosoma antibodies. From this study it could be concluded that HGV is a common co-infection in HCV cases, however there was no significant statistical relation between the presence of HGV RNA and the presence of HBsAg and /or Schistosoma antibodies. Screening for HGV among blood donors in addition to the routinely screened HBV and HCV may have a beneficial effect in reducing its transmission among the population.
\end{abstract}

Key words: HGV, HCV, HBV, Schistosoma

\section{INTRODUCTION}

Viral hepatitis is a major global public in which both non viral causes and health problem. It is the most common infection with any of the five known and cause of chronic hepatitis resulting in liver characterized hepatitis viruses have been fibrosis, cirrhosis, and liver carcinoma.(1) excluded, is described as non-A-E Over the past 40 years, five hepatitis hepatitis. (2) Other hepatitis viruses have viruses have been identified and named $A$, been reported. One of the blood borne B, C, D, and E. Acute or chronic hepatitis, hepatitis viruses is hepatitis G virus. (3)

\footnotetext{
* High Institute of Public Health Department of Microbiology Alexandria University
} 
HGV is a single-stranded, positive sense RNA virus, belonging to the family Flaviviridae. It is a hepatotrophic virus discovered in 1995. ${ }^{(4)}$ It is highly prevalent among volunteer blood donors and general population, as many cases can be chronic carriers for HGV for decads with no symptoms.(5) Although HGV infection alone rarely causes acute hepatitis with transient elevation of liver enzymes, about 10-20\% of infections develop chronic hepatitis with elevated serum ALT levels. ${ }^{(6)}$ HGV RNA was detected in patients with fulminant hepatic failure (FHF) of unknown etiology. ${ }^{(7)} \mathrm{HGV}$ also causes extra hepatic manifestations as hepatitis/ aplastic anaemia syndrome.(8) HGV co-infection with other hepatitis viruses as HCV and HBV will worsen the case of chronic hepatitis leading to more progression and faster hepatic damage and increases the HCC incidence. ${ }^{(9)}$

HGV is transmitted via exposure to blood and blood products; so infection is frequent among multiple transfused haemophiliacs, thalassaemia and haemodialysis patients. ${ }^{(10,11)}$ Other routes of transmission such as sexual, vertical transmission, nosocomial, and intra-familial transmission have been documented. $(12,13)$ HGV infection is diagnosed by reverse transcriptase polymerase chain reaction (RT-PCR). Serological tests for antibodies to envelope E2 protein have been developed, however they indicate past infection only. ${ }^{(14,15)}$

In this study we aimed to determine the prevalence of $\mathrm{HGV}$ among $\mathrm{HCV}$ cases, and to determine the degree of concurrent association between HGV and other prevalent infections in Egypt as Schistosoma, and HBV infections.

\section{SUBJECTS AND METHODS}

This study was carried out through the period from August 2008 to February 2009. It included 100 blood donors attending Alexandria University Blood Bank 
in El Shatby, proved to be positive for HCV antibodies by ELISA technique. They were asked about personal data including; sex, age, occupation, past history of blood transfusion, past history of surgical operations and past history of liver diseases or bilharzial infection. Informed consent was obtained from each patient.

Five $\mathrm{ml}$ blood were aseptically collected from each patient in sterile tubes, sera were separated by centrifugation, distributed into aliquots and stored by deep freezing at $-70^{\circ} \mathrm{C}$ until tested for the detection of HBsAg, Schistosoma antibodies and HGV RNA.

HBsAg was detected using DIMA diagnostic ELISA kit, while Schistosoma antibodies were detected using DRG IgG ELISA kit according to the manufacturer's instructions.

HGV RNA was detected using nested PCR technique.(16) RNA was extracted from $100 \mu \mathrm{l}$ of serum samples by using Promega SV total RNA isolation system and resuspended in $100 \mu \mathrm{l}$ of elution buffer. The extracted RNA was subjected to reverse transcription and DNA amplification, both were done together using the Promega Access Quick RT-PCR System. For first round of amplification outer primers were used:

G58 (outer; forward), 5`-

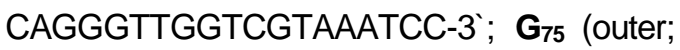
reverse), 5'CCTATTGGTCAAGAGAGACAT3`; The amplification protocol included 25 cycles of denaturation at $94^{\circ} \mathrm{C}$ for 45 seconds, annealing at $55^{\circ} \mathrm{C}$ for 45 seconds and extension at $72^{\circ} \mathrm{C}$ for 90 seconds.

Reamplifications of the resulted amplicons were done using specific inner primers. $\mathbf{G}_{134}$ (inner; forward), 5’GGTCAYCYTGGTAGCCACTATAGG-3; $\mathbf{G}_{131} \quad$ (inner; reverse), 5AAGAGAGACATTGWAGGGCGACGT-3`; The second amplification was done using promega Go Taq Green Master mix with the same amplification protocol. All samples were pre-aliquoted to prevent degradation resulting 
from repeated freezing and thawing. To avoid contamination, sample preparation, DNA extraction, and PCR amplification steps were performed in separate areas. Aerosol filter pipette tips were used for handling all liquids. All appliances, containers, and the work areas were cleaned and irradiated with UV light for at least 60 minutes. One nuclease-free water control was included per 6 samples, and results were negative in all cases.

PCR products resulting from the second round of amplification were loaded on $2 \%$ agarose in Tris-EDTA buffer (TBE) containing $0.5 \mu \mathrm{g}$ of ethidium bromide per milliliter. After electrophoresis, The DNA bands were visualized on a $302 \mathrm{~nm}$ UV transilluminator and photographed. The gel was examined for specific bands of $208 \mathrm{bp}$ as determined by the molecular weight markers run at the same time.

\section{Statistical analysis}

Data were analyzed using SPSS (Statistical Package for the Social Sciences) version 13.0. The association between the categorical variables were assessed by using the chi-square test. $\mathrm{P}$ value $<0.05$ was considered statistically significant.

\section{RESULTS}

Table1 shows that out of 100 anti-HCV positive blood donors, $39(39 \%)$ had HGV RNA in their serum, while the remaining 61(61\%) were HGV RNA negative. Out of 100 anti-HCV positive blood donors, 54 had history of blood transfusion, among them 29 (53.7\%) were HGV RNA positive, while out of 46 patients with no history of blood transfusion, only $10 \quad(21.73 \%)$ patients were HGV RNA positive. The results were statistically significant $\left(X^{2}=\right.$ 10.668, $P=0.001$ ).

Table 2 shows that out of the 39 HGV RNA positive cases, 10 (25.6\%) had HBsAg in their serum, on the other hand $34(87.2 \%)$ were positive for Schistosoma antibodies. On the other hand, out of 61 HGV RNA negative cases, 24(39.3\%) had HBsAg in their serum, 
and 54 (88.5\%) were positive for Schistosoma antibodies. Five (5\%) of the studied patients had HGV RNA, HBsAg and Schistosoma antibodies in their serum, while $17(17 \%)$ patients had only HBsAg and Schistosoma antibodies in their serum in absence of HGV RNA . The results were statistically insignificant $(P>0.05)$.

\section{DISCUSSION}

HGV infection is a worldwide health problem causing acute and chronic non AE hepatitis. Voluntary blood donors are the most dangerous group for the transportation of $\mathrm{HGV}$ infection, careful investigation for the taken blood is the only way to protect others who receive this blood. Several studies showed that there was a very large variation in the prevalence of HGV RNA in healthy blood donors ranging from $1 \%$ to $44 \%$. (17- 20$)$

Because HGV and HCV share same modes of transmission, co-infection with the two viruses is not uncommon especially among people at high risk of parenteral infection. In the present study, HGV RNA was detected by nested PCR technique in 39 (39\%) persons out of 100 anti-HCV positive blood donors. Similar results were reported by many studies as that by Wang et al, (1997) (21) who found that the percent of HGV infection in HCV positive blood donors was $29 \%$. A study by Brojer et al, (1999) (22) estimated HGV co-infection in $22.2 \%$ of HCV chronic cases. Another study by Chu et al, (1999) (23) reported that HGV infection was detected in $17.3 \%$ of chronic HCV patients. Also Yan and Dennin, (2000) (24) found a high frequency (35\%) of HGV co-infection in hepatitis C patients in Germany. Chu et al, (2001) (25) found that co-infection between HGV and HCV was proved in $22 \%$ of patients. Alknawy et al, (2002) (26) reported co-infection between the two viruses in $31 \%$ of Saudi patients. In the United Arab Emirates, the percentage was $47.6 \%$ as reported by Abou Odeh et al, (2005).(27) In 2008, Rajan et al, (20) found that co-infection of HGV and 
$\mathrm{HCV}$ in chronic liver disease cases was $71.4 \%$. While Salehi et al, (2009) ${ }^{(28)}$ stated that the prevalence of HGV and HCV coinfection was $25 \%$.

On the other hand, many studies reported a lower frequency of HGV coinfection among chronic HCV patients ranging from $5 \%-14 \%$. $(16,29-33)$ The low prevalence of HGV infection in $\mathrm{HCV}$ chronic patients in some studies may be attributed to the use of interferon therapy that may lead to HGV RNA clearance in those patients as proved by a study conducted by Yu et al, (2001), (34) where the co-infection rate between HGV and HCV was $35.2 \%$ while after the use of interferon, HGV RNA disappeared in $20.7 \%$ of cases.

In this study, there was significant statistical relation between the presence of HGV RNA and history of blood transfusion as HGV RNA was detected among 29 cases $(53.7 \%)$ with positive history of blood transfusion. A study by Hinrichsen et al,
(2002) (35) reported that repeated blood transfusions more than five times increases the risk of HGV infection significantly. Abad et al, (36) found that the prevalence of HGV RNA in multi-transfused thalassemic patients was $2.24 \%$. In 2008, Samadi et al (37) reported that the number of transfusion of blood and blood products increased the risk of HGV infection.

In this study Schistosoma antibodies were detected in $88(88 \%)$ of anti-HCV positive cases, Out of the 39 HGV RNA cases, $34(87.2 \%)$ were positive for Schistosoma antibodies. Hassoba et al, (1997) (38) reported that the presence of GBV-C RNA was associated significantly with a history of schistosomiasis. Another work by Gallian et al, (1998)(39) studying the prevalence of HGV in rural area in Brazil, in which the prevalence of schistosomiasis was $80-90 \%$, found that the percentage of HGV viremia was $16.4 \%$ and the anti- $E_{2}$ was $18.3 \%$ with a total exposure rate of $34.7 \%$. These findings 
were explained by the presence of carried out by Abu Odeh et al, (2005). (27) Schistosoma infection which influence the Nevertheless, Rajan et al, (2008) (20) immune response to $\mathrm{HGV}$ resulting in documented that the prevalence of HGV RNA delayed viral clearance. Darwish et al, in chronic liver disease cases co-infected with $(1998)^{(1)}$ who studied the prevalence of HBV was $50 \%$.

HGV in Egypt, documented that older age From this study it could be concluded that and history of schistosomiasis were significant factors in the wide spread of HGV in Egypt.

In the present study, HBsAg was $\mathrm{HGV}$ is a common co-infection in $\mathrm{HCV}$ cases. There was significant statistical relation between the presence of $\mathrm{HGV}$ detected among 34 (34\%) of anti-HCV RNA and history of blood transfusion, positive cases, and out of the 39 HGV RNA positive cases, 10 (25.6\%) were positive for HBsAg. As the three hepatotropic viruses are mainly transmitted through blood and blood products, thus co-infection between them can occur in a substantial proportion of patients. A study by Brojer et al, (1999) (22) reported the presence of $\mathrm{HGV}$ infection in $16.6 \%$ of $\mathrm{HBV}$ patients. The prevalence of HGV in HBV cases was $14.3 \%$ according to the study however there was no significant statistical relation between the presence of HGV RNA and the presence of $\mathrm{HBsAg}$ and /or Schistosoma antibodies. Thus, screening for HGV among blood donors in addition to the routinely screened HBV and HCV may have a beneficial effect in reducing its transmission among the population. We should pay more attention to HGV when studying the possible pathogens of the so called "Hepatitis of unknown aetiology" 
Table (1) Distribution of HGV RNA in 100 anti- HCV positive blood donors according to past history of blood transfusion:

\begin{tabular}{|l|c|c|c|c|c|c|}
\hline \multirow{2}{*}{ History of blood transfusion } & \multicolumn{4}{|c|}{ HGV RNA } & \multirow{2}{*}{ Total } & \\
\cline { 2 - 6 } & \multicolumn{2}{|c|}{ Positive } & \multicolumn{2}{|c|}{ Negative } & \\
\cline { 2 - 6 } & No & $\%$ & No & $\%$ & & \multirow{2}{*}{$X^{2}=10.668^{*}$} \\
\hline Yes & 29 & 53.70 & 25 & 46.30 & 54 & P $=0.001$ \\
\hline No & 10 & 21.73 & 36 & 78.27 & 46 & \\
\hline Total & 39 & 39.00 & 61 & 61.00 & 100 & \\
\hline
\end{tabular}

*Significant $\mathrm{p}<0.05$

TABLE (2): HGV RNA, HBsAg and Schistosoma antibodies among 100 anti-HCV positive blood donors:

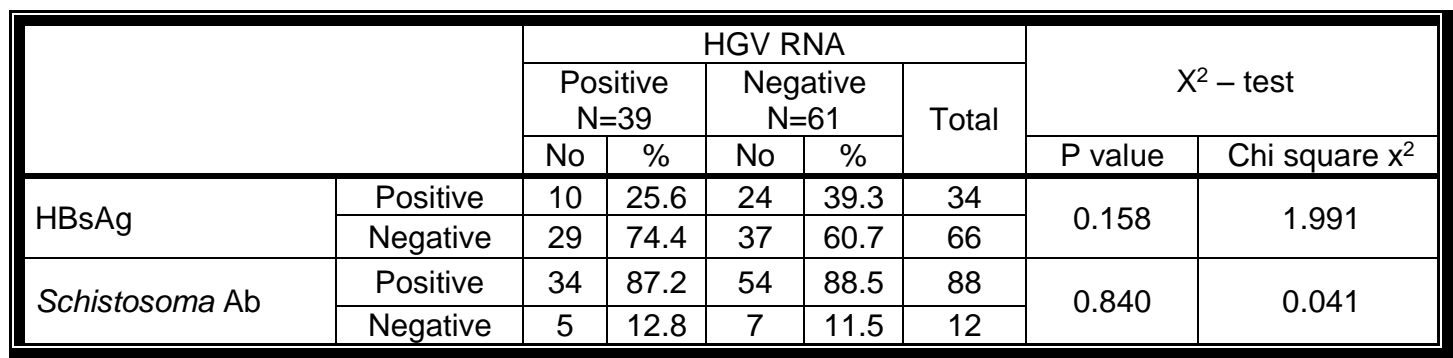

Insignificant $(p>0.05)$

\section{REFERENCES}

1. Darwish MA, Amer AF, El-Moeity AA, Darwish NM. Hepatitis $G$ virus in Egyptians infected with other parenterally transmitted hepatitis viruses. J Egypt Publ Hlth Assoc. 1998; 73 (3-4): 151-64.

2. Choo Q, Kuo G, Weiner A, Overby L, Bradley $D$, Houghton $M$. Isolation of a cDNA clone derived from a blood-borne non-A, non-B viral hepatitis genome. Science. 1989; 244 (4902): 359-62.

3. Linnen J, Wages J, Zhangkeck ZY, Fry $\mathrm{KE}$, Krawczynski KZ, Alter $\mathrm{H}$, et al. Molecular cloning and disease association of HGV, a transfusion transmissible agent. Science. 1996; 271: 505-8.

4. Leary TP, Muerhoff AS, Simons JN. The sequence and genomic organization of GBV-A: A novel member of the flaviviridae associated with human non A-E hepatitis. J Med Virol. 1996; 48: 60-7.

5. Blair CS, Davidson F, Lycett C. Prevalence, incidence and clinical characteristics of hepatitis G virus/ GB virus $C$ infection in Scottish blood donors. J Infect Dis. 2002; 178: 1779-82.

6. Heinsen A, Fomsgaard A. Hepatitis G virus or hepatitis GB virus- C. UgerskLaeger. 1999, 161 (18): 263-6.

7. Yoshiba M, Okamoto $H$, Mishiro $S$. Detection of GB virus C/ hepatitis G virus genome in serum from patients with fulminant hepatitis of unknown aetiology. Lancet. 1995; 346: 1131-2.

8. Zaidi Y, Chapman CS, Myint S. Aplastic anaemia after HGV infection. Lancet. 
1996; 348: 471-2.

9. Berg $T$, Nauman $U$, Fukumoto $T$, Bechstein WO, Neuhaus P, Lobeck $H$, et al. $\mathrm{GB}$ virus $\mathrm{C}$ infection in patients with chronic hepatitis $B$ and $C$ before and after liver transplantation. Transplant. 1996; 62: 711-4.

10.Seifried C, Weber M, Bialleck $H$, Seifried E, Schrezenmeier $H$, Roth WK. High prevalence of GBV-C/HGV among relatives of GBV-C/ HGV-positive blood donors in blood recipients and in patients with aplastic anemia. Transfusion. 2004; 44 (2): 268-74.

11. Masuko K, Mrrsui T, Iwano K. Infection with hepatitis $G B$ virus $C$ patients on maintenance hemodialysis. $\mathrm{N}$ Engl $\mathrm{J}$ Med. 1996; 331(23): 1485-90.

12. Wejstal R, Manson AS, Widell A, Norkrans G. Perinatal transmission of hepatitis $G$ virus (GB virus type $C$ ) and hepatitis $C$ virus infections-a comparison. Clin Infect Dis. 1999; 28: 816-21.

13. Frey SE, Homan SM, Anderson MS, Cayco MT, Cortorreal P, Musial CE, et al. Evidence for probable sexual transmission of the hepatitis $G$ virus. Clin Infect Dis. 2002; 34: 1033-8.

14.Andonov A, Sauder C, Jacobsen H, Chaudhary R. Comparison of six sets of PCR primers from two different genomic regions for amplification of $G B$ virus $C$ / hepatitis $G$ virus RNA. J Clin Microbiol. 1998; 36:286-9.

15. TackeM, KiyosawaK, StarkK, Schlaueter V, Ofenloch- Haehnle B, Hess G, et al. Detection of antibodies to a putative HGV envelope protein. Lancet. 1997; 149: 31820.

16. Eslamifar A, Hamkar R, Ramezani A, Ahmadi F, Gachkar L, Jalilvand S, et al. Hepatitis $G$ virus exposure in dialysis patients. Int Urol Nephrol. 2007; 39:1257-63.

17. Love B, Stanzeit S, Gudmundsson A. Hepatitis $G$ virus infections in Iceland. J Viral Hepat. 1999; 6: 255-60.
18.Yu ML, Chuang WL, Dai C-Y, Lu SN, Wang JH, Huang JF, et al. The serological and molecular epidemiology of $G B$ virus $C$ / hepatitis $G$ virus infection in a hepatitis $C$ and $B$ endemic area. $J$ Infection. 2001; 42 (1): 61-6.

19. El-Semany AAM. Prevalence of hepatitis $G$ virus in chronic cases of hepatitis ( $B$ and C), and HIV in Sanaa, Yemen.2008. (cited 2010 January 1) Available from: www.yemen.nic.info/contents/studies/detail

20. Rajan R, Balakishnan V, Elango EM. Prevalence of hepatitis $G$ virus among chronic liver disease patients and voluntary blood donors in Kerala, India. Int $\mathrm{J}$ Infect Dis. 2008: 12; e 430.

21.Wang Y, Chen HS, Fan MH, Liu HL, An $P$, Sawada $N$, et al. Infection with $G B$ virus $\mathrm{C}$ and hepatitis $\mathrm{C}$ virus in hemodialysis patients and blood donors in Beijing. J Med Virol. 1997; 52: 26-30.

22. Brojer E, Grabarczyk P, Kryczka W, Kucharski W, Kubicka J, Zupanska B. Analysis of hepatitis $G$ virus infection markers in blood donors and patients with hepatitis. J Viral Hepatitis. 1999; 6: 471-4.

23. Chu CM, Lin SM, Hsieh SY, Yeh CT, Lin DY, Sheen IS, et al. Etiology of sporadic acute viral hepatitis in Taiwan: the role of hepatitis $C$ virus, hepatitis $E$ virus and $G B$ virus $-C$ / hepatitis $G$ virus in an endemic area of hepatitis $A$ and $B$. J Med Virol. 1999; 58:154-9.

24. Yan J, Dennin R $H$. A high frequency of GBV-C/HGV co-infection in hepatitis C patients in Germany. WorldJ Gastroenterol. 2000; 6: 833-41.

25. Chu CW, Hwang SJ, Luo JC, Wang YJ, $\mathrm{Lu} \mathrm{RH}$, Lai CR, et al. Clinical, virological, immunological, and pathological significance of GB virus C hepatitis $G$ infection in patients with chronic hepatitis C. Hepatol Research. 2001; 19: (3), 225-36.

26. AlKnawy $B$, Okamoto $H$, ElMekki $A A$, Khalafalla ME, Al Wabel A, Oazi F, et al. Distribution of hepatitis $C$ genotype 
and co-infection rate with hepatitis $G$ in Saudi Arabia. Hepatology Research. 2002; 24 (2): 95-8.

27.Abu Odeh RO, Al Moslih M, AlJokhdar MW, Ezzeddne SA. Detection and genotyping of GBV - $\mathrm{C}$ virus in the United Arab Emirates. J Med Virol. 2005; 76: 534-40

28. Salehi H, Khorvash F, Nokhodian V, Zade M A, Taghian E. Seroepidemiology of HGV in blood donors and patients under hemodialysis. J Isfahan Medical School. 2009;8:36-43.

29.Barusruk S, Uewijitaroon Y. High prevalence of HGV co-infection with HBV or HCV among Northeastern Thai blood donors. Southeast Asian J Trop Med Public Health. 2006; 37: 2, 289-93.

30.El-Zayadi AR, Abe K, Selim O, Naito H, Hess G, Ahdy A. Prevalence of GBV$C /$ hepatitis $G$ virus viraemia among blood donors, health care personnel, chronic non-B non- $C$ hepatitis, chronic hepatitis $\mathrm{C}$ and hemodialysis patients in Egypt. J Virol Methods. 1999; 80: 53-8.

31.Caudai C, Padula MG, Bettini V, Valensin PE. Detection of $\mathrm{HCV}$ and GBV-C/ HGV infection by multiplex PCR in plasma samples of transfused subjects. J Virol Meth. 1998; 70: 79-83.

32. Moriyama M, Matsumura $\mathrm{H}$, Shimizu $\mathrm{T}$, Shioda $A$, Kaneko $M$, Saito $H$, et al. Hepatitis $G$ virus co-infection influences the liver histology of patients with chronic hepatitis C. Liver. 2000; 20: 397-404.

33. Ziaee M, Zarban A, Malekinejad P, Akhbary $\mathrm{H}$. Evaluation of $\mathrm{HGV}$ viremia prevalence and its co-infection with HBV, HCV, HIV and HTLV-1 in hemophilic patients of southern Khorassan, Iran. Hepatitis Monthly. 2007; 7(1): 11-4

34. Yu ML, Chuang WL, Dai CY, Chen SC, Lin ZY, Hsien MY, et al. GB virus C hepatitis $G$ virus infection in chronic hepatitis $C$ patients with and without Interferon - $\alpha$ therapy. Antiviral Research. 2001; $52:$ 241-9.

35. Hinrichsen H, Leimenstoll G, Stegen G, Schrader H, Folsch UR, Schmidt WE. Prevalence of and risk factors for hepatitis $\mathrm{G}$ (HGV) infection in hemodialysis patients: a multicenter study. Nephrol Dial Transplant. 2002; 17: 271-5.

36. Abad SAK, Samiei S, Talebian A, Maghsudloo M, Gharehbaghian A. Hepatitis $G$ virus infection in Iranian blood donors and high - risk groups. Cited in Hepatitis Monthly on line. (cited 2009 March 1) Available from: http://hepmon.com/view/

37. Samadi M, Keyvani H, Moghaddam $\mathrm{SMH}$. Prevalence and risk factors of the hepatitis $\mathrm{G}$ (HGV) infection in hemodialysis patients. Iranian J Clin Inf Dis. 2008; 3 (1): 7-11.

38. Hassoba HM, Terrauit NA, El-Gohary AM, Scheffel C, Jau C, Brackett J, et al. Antibody to GBV-C second envelope glycoprotein (anti-GBV-C $E_{2}$ ): Is it a marker for immunity? J Med Virol. 1997; 53: 354-60.

39.Gallian P, Rodrigues V, Cantaloube JF, Dessein $\mathrm{H}$, Demicco $\mathrm{P}$, Dessein AJ, et al. High prevalence of GB-C/ hepatitis G virus in Brazilian population with helminth infection. J Med Virol. 1998; 56: 310-5. 